\title{
ResearchOnline@JCU
}

This is the author-created version of the following work:

Hall, Leanne M., Ediriweera, Yashodha, Banks, Jennifer, Nambiar, Anjali, and Heal, Clare (2020) Cooling to reduce the pain associated with vaccination: a systematic review. Vaccine, 38 (51) pp. 8082-8089.

Access to this file is available from:

https://researchonline.jcu.edu.au/65970/

Published Version: (C) 2020 Elsevier Ltd. All rights reserved, Accepted Version: Open Access in an Institutional Repository under a CC BY-NC-ND license after an embargo of 12 months.

Please refer to the original source for the final version of this work: 


\section{Cooling to reduce pain associated with vaccination: a systematic}

\section{review}

\section{Abstract}

Background: Vaccine injections are the most common cause of iatrogenic pain in childhood and a cause of anxiety in adulthood. Skin cooling techniques, including icepacks and vapocoolants, may provide pain relief during intramuscular injections.

\section{Objective: To identify the effects of skin cooling techniques on pain associated with} immunisation.

Methods: MEDLINE (Ovid), CINAHL, EMCARE, INFORMIT and Scopus were searched for randomised controlled trials (RCTs) investigating the use of skin cooling techniques on pain associated with vaccination. Study and intervention details, outcomes measures and results were extracted and risk of bias assessed using the Cochrane Risk of Bias tool. Due to heterogeneity of studies, a narrative synthesis was performed.

Results: Thirteen trials were included, involving 689 paediatric and 829 adult participants. All studies used vapocoolant or ice as one of the interventions. Comparator groups included topical EMLA cream, breastfeeding, distraction techniques and tactile stimulation.

Vapocoolant reduced vaccination-related pain in all adult studies and six paediatric studies however the use of ice packs in paediatric patients was not effective.

Conclusion: The use of cooling techniques reduces pain associated with vaccinations in adults. Paediatric studies show mixed results for vapocoolants and an inability for ice to decrease vaccine-injection pain. Larger RCTs are required to determine the most effective administration techniques and optimise the analgesic effects of skin cooling.

\section{Keywords: Pain, vaccination, immunisation, vapocoolant, ice, cooling}


28 Vaccine injections are the most common cause of iatrogenic pain in childhood(1) and anxiety in up to $90 \%$ of adults (2). Injection-associated pain and anxiety is a contributing factor to future non-compliance with scheduled vaccinations throughout the lifespan $(3,4)$. Vaccinations are heralded as saving up to 3 million lives each year (5) and are the cornerstone of herd immunity, therefore interventions to reduce the pain and anxiety of intra-muscular vaccinations, and consequently reduced immunisation rates, warrant further investigation (6). A study of an adult working population found that $97 \%$ of participants chose to receive intranasal influenza vaccine over its injectable equivalent, with $14 \%$ citing fear of injections as the primary reason for choosing the intranasal route of administration (7). Pain associated with immunisation is now recognised as a significant adverse event, and adequate pain management strategies should therefore be incorporated into every vaccination (8).

Previous systematic and literature reviews in paediatric populations $(9,10)$ and combined paediatric and adult populations (11), have investigated interventions to reduce the pain of immunisation. Topical analgesics were found to be effective in both adult (11) and paediatric populations $(9,10)$, as were sucrose solutions, breastfeeding in the $0-2$ year age group (9) and cooling combined with vibration(10) however cooling alone has yielded mixed results.

Cold therapy has been used for centuries to mitigate pain (12). Pain reduction begins at the threshold of $10^{\circ} \mathrm{C}$ and continues to increase as skin temperature approaches $0^{\circ} \mathrm{C}(13)$. The analgesic effect of vapocoolant sprays and ice-packs is further enhanced by their ability to suppress the autonomic responses by decreasing skin conduction level and blood flow (14). In addition to these effects, cooling techniques are considered to be cost-effective and have few, if any, side effects when applied correctly (2).

This review aims to identify and synthesise randomised controlled trials (RCTs) investigating the use of ice or vapocoolant spray to reduce the pain of immunisation in paediatric and adult populations. 
57 This study was prospectively registered with the International Prospective Register of Systematic Reviews (PROSPERO) (CRD42020140084) and guided by the 'Preferred Reporting Items for Systematic Reviews and Meta-Analyses' (PRISMA) guideline (15).

60

61

62

63

\section{Literature search}

A comprehensive literature search, developed in consultation with the Cochrane Collaboration guidelines (16), of the MEDLINE (Ovid), CINAHL, EMCARE, INFORMIT and Scopus databases was conducted on $24^{\text {th }}$ May 2019. . The search strategy included MeSH terms and key words related to the intervention: "immunisation", "vaccinations", "injections", "cold therapy", "ice packs" and "vapocoolant". These search terms were adapted for use with each bibliographic database in combination with database-specific filters. The search was restricted to studies published in the English language. A final search of the databases was conducted on $23^{\text {rd }}$ August 2019 prior to final data analysis.

All articles identified by search were independently screened for eligibility by two reviewers (YE and LH). Bibliographies of included studies were hand-searched for additional articles meeting the selection criteria. Discrepancies between reviewers were resolved by an independent third reviewer $(\mathrm{CH})$.

\section{Selection criteria}

Randomised controlled trials that investigated the use of cold techniques (e.g. ice-packs, vapocoolants) in people undergoing vaccine injections in any setting (e.g. hospital or community) were included. No restrictions were placed on the age of participants. Studies of needle-related procedures other than vaccine injections (e.g. venepuncture and venous cannulation) were excluded.

\section{Data extraction and quality assessment}

Data from included studies were independently extracted into standardised spreadsheets by two reviewers (YE and LH) and compared for accuracy. Discrepancies were resolved by a third reviewer $(\mathrm{CH})$. The following data were tabulated: author name and year, study setting and design, participant characteristics, interventions and outcome measures used, results and key conclusions. 
The methodological quality of included studies was independently assessed by two reviewers (YE and AN) using the Cochrane risk-of-bias tool for RCTs (The Cochrane Collaboration) (16). Disagreements were resolved by a third reviewer (CH). Studies were categorised as low risk of bias if all seven domains were rated as low risk; unclear risk of bias if any domains were rated as unclear; and high risk of bias if one or more domains were rated as high risk.

\section{Outcome measures}

The primary outcome measure was pain associated with vaccination, measured using selfreported pain scales, parent-reported pain scales, infant crying time or infant behaviour scales. A meta-analysis was not possible due to the small sample size, heterogeneity of data and the lack of equivalent comparator groups across studies. Consequently, a narrative synthesis of the data was conducted.

\section{Results}

The search strategy identified 428 studies of potential relevance. After duplicates were removed, 404 studies were screened by title and abstract and 13 full texts assessed for eligibility. Four additional studies were included after manual reference searches (Figure 1). Ten studies involving paediatric participants $(n=689)$ and three involving adult $(>18$ years of age) participants $(n=829)$ undergoing vaccination were included in this review. The majority of trials were conducted in the United States of America $(n=8)$ and Canada $(n=2)$ (Table 1$)$. All studies used ice or vapocoolant as an intervention. The comparator groups were usual care/no intervention (17-23) and/or various physical and pharmacological interventions.

\footnotetext{
These included distraction methods $(17,24,25)$, topical anaesthetic cream (24-26),
} breastfeeding $(21,26)$, cold saline $(2)$, compressed air $(22,27,28)$, and tactile stimulation $(25)$. The number of vaccinations administered during trials ranged from one to six successive injections. Sample sizes tended to be smaller in the paediatric studies than adult studies, with all except Boroumandfar et al having less than 100 participants.

\section{Studies conducted in paediatric populations}

Paediatric studies included infants and children up to 18 years of age, three of which investigated use of cooling techniques with injection of various vaccines, most commonly 
diphtheria-tetanus-pertussis vaccine (acellular and whole-cell forms) $(19,21-24,26-28)$

116 (Table 1). Other vaccinations included measles-mumps-rubella (23), Hepatitis B (21) and

117 tetanus (20). Ice was used as the skin cooling technique in two paediatric studies $(19,20)$,

118 the remaining using vapocoolant either sprayed directly onto the skin $(17,21,26-28)$ or

119 applied via vapocoolant-soaked cotton balls (22-24) in an attempt to control for the

120 potential confounding effect of the spray being perceived as a noxious stimulus.

121 Ice

122 Both studies that assessed the efficacy of ice in reducing pain associated with vaccination

123 found it was ineffective. Self-reported pain levels (Faces Pain rating scale) did not differ with

124 the application of ice for 15 minutes prior to injection of the tetanus vaccine in children

125 aged 10 to 18 years in the study by Ebner et al (20). Application of ice for 30 seconds in the

126 study by Gedaly-Duff and Burns(19) made no difference to pain levels as reported by both

127 the children participating (using the Wong-Baker Faces and Oucher scales) or the observer

128 (using the Global Mood Scale and pulse rate).

\section{Vapocoolant}

130 Five trials showed efficacy of vapocoolant sprays in reducing vaccination pain or distress. Vapocoolant spray and compressed air both reduced pain of vaccination in children aged four to 6 years compared to no intervention (22). From this, Abbott and Fowler (22) concluded that cognitive processes altered pain processing and associated responses such that the placebo intervention was equally as effective as the intervention itself. Boroudmandfar et al (21) concluded from observer assessment using the Neonatal Infant pain scale that both cooling and breastfeeding were superior to usual care in reducing pain but breastfeeding was most effective. In a $2 \times 2$ factorial design that involved vapocoolant spray or compressed air with or without cognitive information, Eland (28) reported reduced pain levels with vapocoolant regardless of the information provided about the intervention and, in contrast to Abbott and Fowler (22), that vapocoolant was more effective at reducing pain than a placebo air spray.

142 Cohen Reiss et al demonstrated that vapocoolant spray (combined with distraction) reduced distress, pain VAS and cry time immediately post-vaccination compared with the distractioncontrol group (24), however differences in distress were not maintained five minutes post- 
injection. No difference was found between vapocoolant spray and EMLA cream. Maikler et al reported that vapocoolant spray did not reduce cry duration compared to compressed air

147 but cry latency and distress behaviours at the time of injection were reduced (27).

148 Three vapocoolant studies found no efficacy for this cooling technique to reduce vaccination 149 pain in the paediatric population. Pain and distress during vaccination, as assessed using 150 self-, carer- and observer-measures, did not differ between vapocoolant and usual care in children aged four to six years in the study by Cohen et al (23). Similarly, Gupta found no evidence of efficacy of vapocoolant sprays post-vaccination (26). These authors concluded that the addition of topical EMLA or vapocoolant spray to breastfeeding does not decrease the duration of cry immediately post-vaccination but both interventions reduced Neonatal Infant Pain Scale scores at one and three minutes after injection (26). The study by Luthy et al relied on parental perceptions of their child's pain and anxiety post-vaccination (17). In contrast to Cohen Reis et al vapocoolant spray was shown to be no more effective than distraction techniques (watching a DVD) or usual care (17).

Ice

161 Of the three studies investigating cooling techniques in adults, only one incorporated ice as one of the intervention arms (18). Ice applied to the skin for 30 seconds was shown to reduce pain during needle insertion and administration of the tetanus vaccine compared to usual care (no treatment) in the study by Akcimen et al (18). There was no difference in pain VAS between ice and vapocoolant spray (a second intervention arm of this study) at the time of needle insertion however scores were significantly lower in the ice group when the vaccine was introduced.

\section{Vapocoolant}

All three adult studies used vapocoolant as an intervention.

170 Akcimen et al (18) reported effectiveness of vapocoolant sprayed directly onto the skin in 171 reducing pain compared to usual care at the time of needle insertion, however pain levels 172 were significantly higher with introduction of tetanus vaccine. 
Mawhorter et al demonstrated a decrease in pain immediately post-vaccination with the application of vapocoolant to the skin via a cotton ball compared to cold saline $\left(4^{\circ} \mathrm{C}\right)(2)$. The difference in pain between the two groups was not evident five minutes post-injection.

177 Taddio et al provided a comparison of vapocoolant spray (applied directly to the skin) to topical anaesthetic (liposomal lidocaine), tactile stimulation and distraction (reading a magazine) (25) that revealed no efficacy for the cooling technique however topical anaesthetic reduced self-perceived pain compared to distraction. Whilst using vapocoolant spray as one of the group allocations, the primary aim of the study by Taddio et al was to determine the effectiveness of topical anaesthesia compared to vapocoolant spray, tactile stimulation and distraction. The effectiveness of vapocoolant and topical anaesthesia did not differ but no summary statistics were provided to allow comparison of vapocoolant to tactile stimulation and distraction.

Risk of bias

Three studies were considered at high risk of bias, two due to lack of or inadequate blinding of participants $(17,18)$ and one due to potential selection bias $(20)$. All other included studies were considered to be at unclear risk of bias (Figure 2).

\section{Discussion}

Thirteen studies that investigated the efficacy of skin cooling techniques in reducing pain associated with vaccinations in adults and children were reviewed. Adult studies more consistently demonstrated a reduction in pain with skin cooling interventions compared to those in the paediatric population. Potential reasons for this include differences in: outcome measures and participant age, comparator groups, vaccine/s administered and application of the cooling technique. Each of these are discussed below.

\section{Outcome measures and participant age}

The subjective nature of pain makes is difficult to measure and often relies on gold standard self-reporting of pain levels using validated instruments e.g. visual analogue scale (VAS). Self-reported scales are not considered applicable to children less than three years of age(29) therefore this difficulty is compounded in infants and young children. As such surrogate measures are used based commonly on behavioural and physiological changes. 
Adult studies in this review relied on self-reported pain using Pain VAS and McGill Present

205

206

207

208

209

210

211

212

213

214

215

216

217

218

219

220

221

222

223

224

225

226

227

228

229

230

231

232

233

Pain Intensity, both of which have been validated $(30,31)$. Paediatric studies relied on several different outcome measures which varied depending on participant age. Luthy et al used parental perception of their child's pain, despite including participants from two to 12 years of age (17). Potential differences in surrogate reports of pain by parents and those the children, as demonstrated by Abbott and Fowler (22), may have self-reported could have contributed to the lack of efficacy of vapocoolant in this study.

\section{Comparator groups}

Not all studies utilised a usual care or no-intervention control group, instead opting to either use a combined intervention in which one component was carried through all comparator groups (e.g. vapocoolant+distraction, EMLA cream+distraction and distraction alone (24)), or a control group that closely resembles the intervention (e.g. vapocoolant spray and compressed air (27)). In each of these cases, the effect of cooling may be mitigated by the effect of the common or comparator intervention. Gupta et al used breastfeeding as an intervention common to each randomised group, however breastfeeding alone has been shown to be effective in reducing pain associated with vaccination (11). It is possible that non-pharmacological interventions act like a filter (e.g. breastfeeding) in which a certain level of pain passes through but higher pain is attenuated. Although additional filters may be added (for example breastfeeding+vapocoolant) the effect of combined filters may be synergistic and therefore the reduction in pain may not be proportional to the effect of each individual intervention filters.

In a similar manner, Ebner conducted her study in a cohort of children receiving tetanus vaccinations in an emergency department after presentation with wounds that potentially required suturing (20). Attention influences the spinal gating mechanism that modulates pain (32). Depending on the severity of the wound, it could garner more attention than the vaccination, in which case the potential analgesic effect of ice may have been diminished by the distraction of the wound itself.

\section{Vaccine/s administered}

The pain or discomfort from the injections is the combined result of local tissue injury from the needle insertion and the introduction of the vaccine, which increases intra-tissue 
pressure as the volume increases. Thus, higher volumes of vaccines may cause more pain at the injection site than lower volumes. Different vaccinations may also be perceived as more painful than others. For example, Burns et al showed that pain scores for Human Papilloma Virus vaccination were higher than Hepatitis A and meningococcal vaccinations(33). Studies in children receiving the DPT vaccine showed vapocoolant was effective (either immediately or within 3 minutes of injection) in reducing pain levels.

240 The number of vaccinations administered differed between trials. All studies that used vapocoolant in infants and children who received two or less vaccines in the one consultation reported positive effects of cooling either immediately $(21,22,24,27,28)$ or post-vaccination (26). Those that allowed for multiple injections $(17,23)$ had less favourable outcomes. This did not hold true in single-injection paediatric studies that used an ice intervention. The order of injection of multiple vaccinations can affect the pain response in infants given the first injection may focus attention and stimulate pain-processing mechanisms that intensify subsequent signals (34). Neither study that allowed for multiple vaccinations stated if the order of vaccine administration was randomised.

\section{Application of cooling techniques}

250

Any intervention applied prior to injection could focus participant's attention on the site to which it is applied and heighten the pain response. Vapocoolants cause cold and often burning sensations of the skin that can be perceived as noxious stimuli, increasing distress and anxiety (23) and potentially mitigating any benefit from their application. Eight studies across the lifespan demonstrated a benefit of vapocoolants in reducing vaccination pain, therefore this is unlikely to explain the inconsistent results.

There appears to be little consensus on the most effective technique to apply cooling interventions. This review identified studies that applied ice for as little as $30 \mathrm{~s}(18,19)$ or up to 15 minutes (20). The time for which vapocoolants were applied was less variable (2-10 s when sprayed directly onto the skin and 10-20 s when applied via soaked cotton balls) and reflects the potential for these volatile liquids to cause skin freezing. These differences in the technique used in applying the intervention do not account for the variable results. Both paediatric studies that used ice as an intervention showed no difference in pain levels compared to usual care despite the short and long durations of application. Similarly, 
studies in similar aged participants that used soaked cotton balls as a vehicle for vapocoolants had contradicting results $(22,23)$.

Limitations

267

The methodological heterogeneity of the included trials in terms of sample size, intervention, comparator groups and measured outcomes meant a meaningful metaanalysis could not be performed. Additionally, although there were 10 paediatric studies, compared to three in the adult population, their numbers contributed to only $45 \%$ of total participants studied, indicating a need for larger scale RCTs in this group.

Another limitation of this review is that all studies were considered to be either at unclear $(n=10)$ or high risk of bias (Figure 2), commonly due to performance and reporting biases. The results of this review should therefore be interpreted with caution.

The effectiveness of vapocoolant in the study by Taddio et al (25) was difficult to determine as it was compared to other interventions without a usual care or no-intervention control. The remaining two studies $(2,18)$ suggest that skin cooling using vapocoolant sprays can be recommended as a form of analgesia to reduce pain associated with vaccine injections in adults. Ice shows promise in mitigating immediate vaccination-related pain (18) but further research is required to replicate these findings.

\section{Clinical implications}

Further research is needed to assess the effectiveness of skin cooling techniques, particularly in infants and children, as a viable method of reducing immunisation pain. However, based on current evidence, the use of vapocoolant sprays in adults can successfully be implemented in primary healthcare settings. Both ice and vapocoolant have few adverse effects, are cost effective and can be easily applied to injection sites. Vapocoolants have the advantage of providing instantaneous cooling effects to the skin, increasing efficiency while ice has widespread availability with minimal cost.

\section{Conclusions}

The use of skin cooling techniques may effectively reduce the pain associated with vaccineinjections. Whilst paediatric study findings are inconclusive, this review concludes that the use of vapocoolant spray and ice in adults can successfully decrease pain associated with vaccination. More rigorous and larger-scale RCT study designs are needed to determine the 
294 effectiveness and applicability of skin cooling techniques for reducing immunisation pain in

295 primary healthcare settings. These should aim to determine to what extent pain mitigation

296 is dependent on the nature of the intervention, the specific vaccine, and age group of 297 participants.

298

299 Acknowledgements

300 The authors would like to thank Mr Stephen Anderson, medical librarian, James Cook

301 University, for his assistance with this systematic review.

302 Funding

$303 \mathrm{Nil}$

304 Conflict of interest statements

305 None of the authors have any conflict of interests to declare. 
307 1. Schechter, N.L., et al., Pain reduction during pediatric immunizations: evidence-based review and recommendations. Pediatrics, 2007. 119(5): p. e1184-98.

309

310

311

312

313

314

315

316

317

318

319

320

321

322

323

324

325

326

327

328

329

330

331

332

333

334

335

336

337

338

339

340

341

342

343

344

345

2. Mawhorter, S., et al., Topical vapocoolant quickly and effectively reduces vaccineassociated pain: results of a randomized, single-blinded, placebo-controlled study. J Travel Med, 2004. 11(5): p. 267-72.

3. Nir, Y., et al., Fear of injections in young adults: prevalence and associations. Am J Trop Med Hyg, 2003. 68(3): p. 341-4.

4. Taddio, A., et al., From the mouth of babes: Getting vaccinated doesn't have to hurt. Can J Infect Dis Med Microbiol, 2014. 25(4): p. 196-200.

5. Organization, W.H. Immunization coverage. [Internet] 2019 [cited 202015 March]; Available from: https://www.who.int/news-room/fact-sheets/detail/immunizationcoverage.

6. Organization, W.H., Weekly epidemiological record. 2014: Switzerland. p. 561-576.

7. Sendi, P., et al., Intranasal influenza vaccine in a working population. Clin Infect Dis,

8. Gidudu, J.F., et al., Immunization site pain: case definition and guidelines for collection, analysis, and presentation of immunization safety data. Vaccine, 2012. 30(30): p. 4558-77.

9. Shah, V., A. Taddio, and M.J. Rieder, Effectiveness and tolerability of pharmacologic and combined interventions for reducing injection pain during routine childhood immunizations: Systematic review and meta-analyses. Clinical Therapeutics, 2009. 31(SUPPL. 2): p. S104-S151.

10. Lee, V.Y., et al., Improving vaccine-related pain, distress or fear in healthy children and adolescents- $a$ systematic search of patient-focused interventions. Hum Vaccin Immunother, 2018. 14(11): p. 2737-2747.

11. Shah, V., et al., Pharmacological and Combined Interventions to Reduce Vaccine Injection Pain in Children and Adults: Systematic Review and Meta-Analysis. Clin J Pain, 2015. 31(10 Suppl): p. S38-63.

12. Auerbach, P., Physical methods for treatment of pain, in Wilderness Medicine, Mosby, Editor. 2007, An Imprint of Elsevier.

13. Travell, J., Factors affecting pain of injection. J Am Med Assoc, 1955. 158(5): p. 36871.

14. Saeki, Y., Effect of local application of cold or heat for relief of pricking pain. Nurs Health Sci, 2002. 4(3): p. 97-105.

15. Moher D, L.A., Tetzlaff J, Althman D G, Group P, Preferred reporting items for systematic reviews and meta-analyses: the PRISMA statement. J Clin Epidemiol, 2009. 62(10): p. 1006- 1012.

16. Higgins, J.P., et al., The Cochrane Collaboration's tool for assessing risk of bias in randomised trials. BMJ, 2011. 343: p. d5928. 
17. Luthy, K.E., R.L. Beckstrand, and A. Pulsipher, Evaluation of methods to relieve parental perceptions of vaccine-associated pain and anxiety in children: a pilot study. Journal of Pediatric Health Care, 2013. 27(5): p. 351-8.

18. Akcimen, M., C. Bedel, and F. Selvi, Application of ice and vapocoolant spray to reduce tetanus vaccine pain: A prospective, randomized, controlled, clinical study. Annals of Medical Research, 2019. 26(6).

19. Gedaly-Duff, V. and C. Burns, Reducing children's pain-distress associated with injections using cold: a pilot study. J Am Acad Nurse Pract, 1992. 4(3): p. 95-100.

20. Ebner, C.A., Cold therapy and its effect on procedural pain in children. Issues Compr Pediatr Nurs, 1996. 19(3): p. 197-208.

21. Boroumandfar, K., et al., Comparison of vaccination-related pain in infants who receive vapocoolant spray and breastfeeding during injection. Iran J Nurs Midwifery Res, 2013. 18(1): p. 33-7.

22. Abbott, K. and S. Fowler-Kerry, The use of a topical refrigerant anesthetic to reduce injection pain in children. J Pain Symptom Manage, 1995. 10(8): p. 584-90.

23. Cohen, L.L., et al., A randomized controlled trial of vapocoolant for pediatric immunization distress relief. Clin J Pain, 2009. 25(6): p. 490-4.

24. Cohen Reis, E. and R. Holubkov, Vapocoolant spray is equally effective as EMLA cream in reducing immunization pain in school-aged children. Pediatrics, 1997. 100(6): p. E5.

25. Taddio, A., et al., A randomized controlled trial of analgesia during vaccination in adults. Vaccine, 2010. 28(32): p. 5365-9.

26. Gupta, N.K., et al., Randomized controlled trial of topical EMLA and vapocoolant spray for reducing pain during WDPT vaccination. World J Pediatr, 2017. 13(3): p. 236-241.

27. Maikler, V.E., Effects of a skin refrigerant/anesthetic and age on the pain responses of infants receiving immunizations. Res Nurs Health, 1991. 14(6): p. 397-403.

28. Eland, J.M., Minimizing pain associated with prekindergarten intramuscular injections. Issues Compr Pediatr Nurs, 1981. 5(5-6): p. 361-72.

29. Mathew, P.J. and J.L. Mathew, Assessment and management of pain in infants. Postgrad Med J, 2003. 79(934): p. 438-43.

30. Melzack, R., The McGill Pain Questionnaire: major properties and scoring methods. Pain, 1975. 1(3): p. 277-99.

31. Su, L., et al., Measuring injection-site pain associated with vaccine administration in adults: a randomised, double-blind, placebo-controlled clinical trial. J Epidemiol Biostat, 2000. 5(6): p. 359-65.

32. Melzack, R. and P.D. Wall, Pain Mechanisms: A New Theory. Science, 1965. 150(3699): p. 971-979.

33. Joseph Burns, J., et al., A Blinded Comparison of Injection Pain With Quadrivalent Human Papilloma Virus Vaccine Versus Other Vaccines. J Pediatric Infect Dis Soc, 2015. 4(4): p. 396-7. 
34. Ipp, M., et al., Order of Vaccine Injection and Infant Pain Response. Archives of 
391 Figure 1: PRISMA flow diagram

392 Figure 2: Summary of risk of bias - Author's assessment of methodological quality of 393 individual studies. Low risk in green (+), unclear risk in yellow (?), high risk in red (-). 394

395

396 


\begin{tabular}{|c|c|c|c|c|c|c|c|}
\hline $\begin{array}{l}\text { First author, } \\
\text { year, country }\end{array}$ & $\begin{array}{l}\text { Participant } \\
\text { age }\end{array}$ & $\begin{array}{l}\text { Vaccine and injection } \\
\text { details [number of } \\
\text { vaccinations } \\
\text { received] }\end{array}$ & $\begin{array}{l}\text { Cooling } \\
\text { Intervention }\end{array}$ & $\begin{array}{l}\text { How cooling } \\
\text { applied to } \\
\text { skin } \\
\text { (application } \\
\text { time) }\end{array}$ & Comparator group & $\begin{array}{l}\text { Outcome measures } \\
\text { (reported by) }\end{array}$ & $\begin{array}{l}\text { Results (cooling } \\
\text { intervention compared } \\
\text { to comparator group/s) }\end{array}$ \\
\hline \multicolumn{8}{|l|}{$\begin{array}{l}\text { PEDIATRIC } \\
\text { STUDIES }\end{array}$} \\
\hline $\begin{array}{l}\text { Abbott } 1995 \\
\text { Canada (22) }\end{array}$ & $\begin{array}{l}4-5.5 y \\
(n=90)\end{array}$ & $\begin{array}{l}\text { DPT; IM; deltoid } \\
\text { muscle - needle gauge } \\
\text { and volume of } \\
\text { injectable solution } \\
\text { constant but length of } \\
\text { needle and injection } \\
\text { technique varied [1] }\end{array}$ & $\begin{array}{l}\text { Refrigerant } \\
\text { topical } \\
\text { anesthetic } \\
\text { spray } \\
\text { (Fluroethyl) } \\
\text { (n=30) }\end{array}$ & $\begin{array}{l}\text { Soaked } \\
\text { cotton ball } \\
(10 \mathrm{~s})\end{array}$ & $\begin{array}{l}\text { 1) Placebo topical } \\
\text { spray } \\
\text { (compressed air + } \\
\text { Freon) via sterile } \\
\text { cotton ball for } 10 \mathrm{~s} \\
(\mathrm{n}=30) \text {; } \\
\text { 2) No-treatment } \\
\text { control }(n=30)\end{array}$ & $\begin{array}{l}\text { Pain VAS (child); Anxiety } \\
\text { and expected pain VAS } \\
\text { (parent) }\end{array}$ & $\begin{array}{l}\text { 1) No difference } \\
\text { 2) Anesthetic spray } \\
\text { reduced pain compared } \\
\text { to no-treatment control }\end{array}$ \\
\hline $\begin{array}{l}\text { Boroumandfar } \\
2013 \text { Iran (21) }\end{array}$ & $\begin{array}{l}<6 \text { mo } \\
(n=144)\end{array}$ & $\begin{array}{l}\text { Hepatitis B (35\%) and } \\
\text { DTP (65\%); injection } \\
\text { details NR [2] }\end{array}$ & $\begin{array}{l}\text { Vapocoolant } \\
\text { spray }(n=48)\end{array}$ & $\begin{array}{l}\text { Directly to } \\
\text { injection site } \\
\text { (1-3 s from } \\
15 \mathrm{~cm} \text { away) }\end{array}$ & $\begin{array}{l}\text { 1) Breastfeeding } \\
(n=48) \\
\text { 2) No-treatment } \\
\text { control }(n=48)\end{array}$ & $\begin{array}{l}\text { Neonatal infant } \\
\text { pain scale (NIPS) } 2 \text { pain } \\
\text { assessment checklist } \\
\text { (researcher) }\end{array}$ & $\begin{array}{l}\text { 1) Frequency of painless } \\
\text { injection higher in } \\
\text { breastfeeding group } \\
\text { than vapocoolant group } \\
\text { 2) Vapocoolant spray } \\
\text { reduced pain severity } \\
\text { compared to no- } \\
\text { treatment control } \\
\text { group }\end{array}$ \\
\hline $\begin{array}{l}\text { Cohen } 2009 \\
\text { USA (23) }\end{array}$ & $\begin{array}{l}4-6 y \\
(n=57)\end{array}$ & $\begin{array}{l}\text { DPTaP, measles- } \\
\text { mumps-rubella and } \\
\text { inactive polio vaccine; } \\
25-G 1 \text { inch needle in } \\
\text { thigh [3] }\end{array}$ & $\begin{array}{l}\text { Vapocoolant } \\
\text { (Ethyl } \\
\text { Chloride) } \\
(n=31)\end{array}$ & $\begin{array}{l}\text { Soaked } \\
\text { cotton ball } \\
(20 \mathrm{~s})\end{array}$ & $\begin{array}{l}\text { No-treatment } \\
\text { control }(n=26)\end{array}$ & $\begin{array}{l}\text { Faces pain scale revised } \\
\text { (child); Baseline distress VAS } \\
\text { (parent and nurse); } \\
\text { Immunisation distress VAS } \\
\text { (parent and nurse); }\end{array}$ & No difference \\
\hline
\end{tabular}


Observational distress

(researcher)

\section{Cohen Reis 4-6 y}

Prior experience VAS
1997 USA (24) (n=62)

$\begin{array}{ll}\begin{array}{ll}\text { Ebner 1996 } \\ \text { USA (20) }\end{array} & \begin{array}{l}10-18 y \\ (\mathrm{n}=40)\end{array} \\ \text { Eland 1981 } & \begin{array}{l}\text { 4y9mo to } \\ 5 y 9 m o \\ \text { USA (28) }\end{array} \\ & \begin{array}{l}n=40)\end{array}\end{array}$

$\begin{array}{ll}\text { Gedaly-Duff } & 4-6 \text { y } \\ 1992 \text { USA (19) } & (n=38)\end{array}$
Ice $(n=N R)$

DPT 0.5 ml; IM; 25-G

$5 / 8$ inch needle in

vastus lateralis [1]

DPT $(78 \%)$ or DT

(22\%); 25-G 5/8 inch needle $(84 \%)$;

deltoid (76\%) [1]

Frigiderm

spray +

cognitive

information

( $n=10)$ OR

cognitive

$(n=10)$

Ice $(n=19)$
Frigiderm + no

information

$\begin{array}{ll}\text { DTaP; IM; 26-G 1/2 } & \text { Vapocoolant } \\ \text { inch needle in deltoid } & \text { (Fluori- } \\ {[1]} & \text { Methane) } \\ & \text { spray + } \\ & \text { distraction } \\ & (n=20)\end{array}$

Soaked
cotton ball
$(15 \mathrm{~s})$

\section{1) EMLA cream}

for

$60 \mathrm{~min}+$ distraction

(blow on pinwheel)

$(n=21)$

2) Distraction alone (control) $(n=21)$ (parent); Global mood scale

(researcher); Observation

scale of behaviour distress

(researcher); Linear pain

VAS (parent, nurse,

researcher); Faces scale

(child, parent, researcher,

nurse); Cry duration

(researcher); Parental

distress VAS (parents own

level of distress), Parental

preference VAS (parents)

Faces Pain rating scale

(child)

No-treatment

(15 mins)

Directly to

control ( $n=N R)$

1) Aerosol air spray + Colour assessment tool

(child); Anxiety (parent and

nurse)

information $(n=10)$

2) Aerosol air spray

$(n=10)$. Spray applied

3-5 s on the leg

before

vaccination

Bag on No-treatment

Global mood scale (GMS)

injection site control $(n=19)$

(30 s)

1) No difference

2) Vapocoolant reduced

injection pain

compared to control

group for all measures

except Global mood

scale (researcher)

No difference

1) Frigiderm spray

reduced pain compared

to air spray + cognitive

information;

2) Frigiderm spray

reduced pain compared

to air spray

No difference

observer); Radial pulse rate

(observer); Oucher scale

and Wong-Baker Faces scale

(child) 


\begin{tabular}{|c|c|c|c|c|c|c|c|}
\hline $\begin{array}{l}\text { Gupta } 2017 \\
\text { India (26) }\end{array}$ & $\begin{array}{l}<3 \mathrm{mo} \\
(\mathrm{n}=90)\end{array}$ & $\begin{array}{l}\text { wDPT; IM; 23-G } 1 \text { inch } \\
\text { needle in } \\
\text { anterolateral thigh [1] }\end{array}$ & $\begin{array}{l}\text { Vapocoolant } \\
\text { spray }+ \\
\text { breastfeeding } \\
(n=30)\end{array}$ & $\begin{array}{l}\text { Directly to } \\
\text { injection site } \\
\text { ( } 2 \text { s from } 12 \\
\text { cm away) }\end{array}$ & $\begin{array}{l}\text { 1) EMLA cream 1g } \\
\text { for } 60 \text { mins }+ \\
\text { breastfeeding }(n=30) \\
\text { 2) Breastfeeding only } \\
(n=30)\end{array}$ & $\begin{array}{l}\text { Duration of first cry } \\
\text { (observer); Latency of cry } \\
\text { (observer); Modified Facial } \\
\text { Coding Score (MFCS) } \\
\text { (observer); Neonatal infant } \\
\text { pain scale (observer) }\end{array}$ & $\begin{array}{l}\text { 1) Comparison not } \\
\text { provided } \\
\text { 2) VP+BF scores for } \\
\text { MFCS and neonatal } \\
\text { pain scale lower } \\
\text { compared with } \\
\text { breastfeeding only at } 1 \\
\text { and } 3 \text { minutes post } \\
\text { injection, no difference } \\
\text { immediately post } \\
\text { insertion }\end{array}$ \\
\hline $\begin{array}{l}\text { Luthy } 2013 \\
\text { USA (17) }\end{array}$ & $\begin{array}{l}2-12 y \\
(n=68)\end{array}$ & $\begin{array}{l}\text { Vaccine NR; injection } \\
\text { details NR [1->4] }\end{array}$ & $\begin{array}{l}\text { Vapocoolant } \\
\text { spray }(n=18)\end{array}$ & $\begin{array}{l}\text { Directly to } \\
\text { injection site } \\
(3-7 \mathrm{~s})\end{array}$ & $\begin{array}{l}\text { 1) Distraction (DVD } \\
\text { before, } \\
\text { during, and after } \\
\text { injection ( } n=27) \\
\text { 2) } \\
\text { No-treatment } \\
\text { control }(n=22)\end{array}$ & $\begin{array}{l}\text { Wong-Baker FACES pain } \\
\text { rating scale (parents); } \\
\text { Anxiety (parents); } \\
\text { Comparison with previous } \\
\text { vaccination (parents); } \\
\text { Preference for same } \\
\text { treatment in future } \\
\text { vaccinations (parents) }\end{array}$ & $\begin{array}{l}\text { 1) FACES pain scale and } \\
\text { Anxiety: no difference } \\
\text { 2) FACES pain scale and } \\
\text { Anxiety: no difference }\end{array}$ \\
\hline $\begin{array}{l}\text { Maikler } 1991 \\
\text { USA (27) }\end{array}$ & $\begin{array}{l}6-30 \\
\text { weeks } \\
(n=60)\end{array}$ & $\begin{array}{l}\text { DPT; IM; } 25-G 5 / 8- \\
\text { inch needle in } \\
\text { anterior thigh [1] }\end{array}$ & $\begin{array}{l}\text { Frigiderm } \\
\text { spray } \\
\text { (dicholortetra- } \\
\text { fluorethane) } \\
(n=30)\end{array}$ & $\begin{array}{l}\text { Directly to } \\
\text { injection site } \\
(2-3 \mathrm{~s})\end{array}$ & $\begin{array}{l}\text { Compressed air } \\
\text { spray ( } 2-3 \text { s directly } \\
\text { to skin) }(n=30)\end{array}$ & $\begin{array}{l}\text { Maximally Discriminative } \\
\text { Facial Movement Coding } \\
\text { System (MAX) (researcher); } \\
\text { Cry type, latency and } \\
\text { duration (researcher); Body } \\
\text { movement, movement } \\
\text { latency, number of } \\
\text { movements, startle } \\
\text { response and symmetry of } \\
\text { movement (researcher) }\end{array}$ & $\begin{array}{l}\text { Frigiderm spray } \\
\text { reduced startle at } \\
\text { needle insertion, } \\
\text { increased cry latency } \\
\text { and reduced movement } \\
\text { symmetry compared to } \\
\text { air spray }\end{array}$ \\
\hline
\end{tabular}

ADULT

STUDIES 


\begin{tabular}{|c|c|c|c|c|c|c|c|}
\hline \multirow[t]{2}{*}{$\begin{array}{l}\text { Akcimen } 2019 \\
\text { Turkey (18) }\end{array}$} & \multirow[t]{2}{*}{$\begin{array}{l}>18 y \\
(n=292)\end{array}$} & \multirow[t]{2}{*}{$\begin{array}{l}\text { Tetanus } 1 \text { ml; IM; } 25- \\
\text { G needle in deltoid [1] }\end{array}$} & 1) Ice $(n=107)$ & $\begin{array}{l}\text { Ice: cube in } \\
\text { latex glove } \\
(30 \mathrm{~s})\end{array}$ & $\begin{array}{l}\text { No-treatment } \\
\text { control }(n=95)\end{array}$ & \multirow[t]{2}{*}{ Pain VAS (patient) } & $\begin{array}{l}\text { 1) Ice reduced pain } \\
\text { compared to control } \\
\text { group }\end{array}$ \\
\hline & & & $\begin{array}{l}\text { 2) } \\
\text { Vapocoolant } \\
\text { spray } \\
\text { (Nexcare } \\
\text { Coldhot) } \\
\text { (n=90) }\end{array}$ & $\begin{array}{l}\text { Vapocoolant: } \\
\text { directly to } \\
\text { injection site } \\
\text { (10 s from } 10 \\
\text { cm away) }\end{array}$ & & & $\begin{array}{l}\text { 2) Vapocoolant reduced } \\
\text { pain compared to } \\
\text { control group }\end{array}$ \\
\hline $\begin{array}{l}\text { Mawhorter } \\
2004 \text { USA (2) }\end{array}$ & $\begin{array}{l}>18 y \\
(n=185)\end{array}$ & $\begin{array}{l}\text { Varied travel vaccines; } \\
\text { IM and SC; injection } \\
\text { details NR [2-6] }\end{array}$ & $\begin{array}{l}\text { Vapocoolant } \\
\text { (Fluori- } \\
\text { methane) } \\
(n=93)\end{array}$ & $\begin{array}{l}\text { Soaked } \\
\text { cotton ball } \\
(15 \mathrm{~s})\end{array}$ & $\begin{array}{l}4^{\circ} \mathrm{C} \text { saline via cotton } \\
\text { ball prior to injection } \\
(n=92)\end{array}$ & $\begin{array}{l}\text { McGill present pain } \\
\text { intensity (PPI) (patient) }\end{array}$ & $\begin{array}{l}\text { Vapocoolant reduced } \\
\text { immediate injection } \\
\text { pain compared to } \\
\text { untreated arm; effect } \\
\text { not maintained at } 5 \\
\text { minutes post injection }\end{array}$ \\
\hline \multirow[t]{3}{*}{$\begin{array}{l}\text { Taddio } 2010 \\
\text { Canada (25) }\end{array}$} & \multirow[t]{3}{*}{$\begin{array}{l}\text { Adults } \\
(n=352)\end{array}$} & \multirow[t]{3}{*}{$\begin{array}{l}\text { H1N1 virus vaccine } \\
0.5 \mathrm{~mL}, 22-\mathrm{G} 1 \text { inch } \\
\text { needle in middle } \\
\text { deltoid [1] }\end{array}$} & \multirow{3}{*}{$\begin{array}{l}\text { Vapocoolant } \\
\text { spray } \\
\text { (PainEase } \\
\text { Medium } \\
\text { spray) }(\mathrm{n}=88)\end{array}$} & \multirow{3}{*}{$\begin{array}{l}\text { Directly to } \\
\text { injection site } \\
\text { within } 60 \mathrm{~s} \\
\text { of injection } \\
(4-10 \mathrm{~s})\end{array}$} & $\begin{array}{l}\text { 1) } 1-2 \mathrm{~g} \text { of liposomal } \\
\text { lidocaine } 4 \% \text { cream } \\
\text { on injection site for } \\
20-30 \text { mins ( } n=88)\end{array}$ & \multirow{3}{*}{$\begin{array}{l}\text { Pain VAS (patient); Anxiety } \\
\text { VAS (patient); Predicted } \\
\text { pain VAS (patient); Global } \\
\text { assessment of intervention } \\
\text { (patient) }\end{array}$} & $\begin{array}{l}\text { 1) No difference } \\
\text { 2) Comparison not } \\
\text { provided }\end{array}$ \\
\hline & & & & & $\begin{array}{l}\text { 2) Nurse-directed } \\
\text { tactile stimulation } \\
\text { for } 10 \mathrm{~s} \text { before and } \\
\text { during injection } \\
(\mathrm{n}=88)\end{array}$ & & $\begin{array}{l}\text { 3) Comparison not } \\
\text { provided }\end{array}$ \\
\hline & & & & & $\begin{array}{l}\text { 3)Self-directed } \\
\text { distraction before } \\
\text { and during injection } \\
(n=88)\end{array}$ & & \\
\hline
\end{tabular}

$399 \mathrm{DPT}=$ diphtheria, pertussis, tetanus; $\mathrm{DTaP}=$ diphtheria, tetanus, acellular pertussis; IM = intramuscular; NR = not reported; VAS = visual

400 analogue scale; $\mathrm{wDPT}=$ whole cell diphtheria, pertussis, tetanus. 